\title{
EFFORTS TO IMPROVE THE QUALITY OF DRUG PACKAGING BY IMPLEMENTING QUALITY FUNCTION DEPLOYMENT (QFD)
}

\author{
Popy Yuliarty ${ }^{1}$; Dewi Sri Raras ${ }^{2}$ Rini Anggraini ${ }^{3}$; Atiek Ike Wijayanti ${ }^{4}$
}

\author{
Department of Industrian Engineering Universitas Mercu Buana, Jakarta $11650^{12}$ \\ Department of Mechanical Engineering Universitas Mercu Buana, Jakarta $11650^{3}$ \\ Department of Industrian Engineering Sekolah Tinggi Teknologi Bina Tunggal, Bekasi $17134^{4}$
}

Corresponding author : popy.yuliarty@mercubuana.ac.id ${ }^{1}$; popy3yuliarty@gmail.com ${ }^{1}$; rinianggraini@mercubuana.ac.id ${ }^{2}$; atiek_ike@yahoo.com ${ }^{3}$

\section{DOI $10.26821 /$ IJSHRE.8.8.2020.8804>}

\begin{abstract}
Abstract: In a manufacturing industry, quality products are one of the most important parts. At present there are many companies engaged in printing medicine and food packaging. Packaging is one of the most important factors because of its function and use in improving product quality and selling power of a drug. The level of competition in the field of industry is getting tougher, it encourages PT. XYZ to develop new products and to improve the quality of existing products. One of the new products that will be developed by $P T$. XYZ using the Quality Function Deployment method is a type of Polycellonium strip packaging. From HoQ Level 1, it is found that the quality of raw materials is the Technical Requirement with top priority. Then the next analysis is carried out again to HoQ Level 2 to find the Process Requirement and Inspection of Jumbo Lamination after curing is a top priority. From the results of the analysis of $H o Q 2$, the analysis is continued to $H o Q 3$, which is Quality Procedure and it is found that the training refreshment procedure once every 6 months is a top priority that can be developed by the company.
\end{abstract}

Keywords: product development, manufacture, medicine packaging, Quality Function Deployment.

\section{INTRODUCTION}

The product is the output obtained from a production process (transformation) and is the addition of value from raw materials and is a commodity sold by the company to consumers [1]. Product design and development are all processes related to the existence of products which include all activities ranging from identification of consumer desires to fabrication, sales and delivery of products. Product design and development is part of an innovation process that exists in the business world. Through product design and development, it is hoped that new product innovations will be able to provide certain advantages in overcoming competition with competitor products. [2]. At present there are many companies engaged in printing medicine and food packaging. Packaging is one of the most important factors because of its function and use in improving product quality and selling power of a drug [3]. The level of competition in the industry is getting tougher, this is encouraging drug packaging printing companies to develop new products and to improve the quality of existing products. In efforts to improve quality product, PT. XYZ needs to identify characteristics of consumer needs. Process identification of consumer needs aimed at know the important attributes and relates to customer satisfaction as a basis for development next product.[4]

One of the new products to be developed is the Polycellonium strip packaging. This type of packaging has many advantages over other types of packaging and is quite attractive to some consumers from leading drug companies [5]. Polycellonium is the material for the most common drug strips containing polycello / cellophane and aluminum layers. Both types of layers have their respective functions to protect the packaged drug. The specifications of the resulting Polycellonium packaging must also be seen from the side of the stripping and branding machine of the consumer (drug manufacturer). Consumer satisfaction is a major issue that must be done in-depth study, so we must know the extent to which consumers get a sense of satisfaction from services and products. Customer satisfaction can be measured by various methods. In this case it can be done by using the QFD (Quality Function Deployment) method development. With the application of this method the company is expected to meet the desires of consumers so they can provide the best products and can survive in the 
Volume 8 Issue 8 August 2020

market [6]. The problem that occurs in the object of this research is that the polycellonium packaging has not been used on this product, so it is necessary to conduct a study to innovate the development of packaging products made from polycelloniumu to fulfill consumer demand.

The objectives of this research are: finding out what attributes are the needs of consumers for polycellonium type drug packaging products. And developing products with the QFD method

\section{Research Methodology}

The planning and development phase of the QFD model can also be called a matrix, while the planning and development matrix of QFD is as follows [7]:

1. Product / House of Quality / HOQ Planning Matrix.HOQ is better known as the first house (R1), which explains about customer needs, technical requirements, co-relationships, relationships, customer copetitive evaluation, competitive technical assessment and budgeting. HOQ consists of 7 main parts.

2. Part Deployment Matrix. Better known as the second house (R2) is a matrix to identify technical factors that are critical to product development.

3. Process planning matrix (R3) which is a matrix to identify the development process of making a product

4. Manufacturing / Production / Manufacturing Production Planning Matrix. Better known as the fourth house (R4), which describes the actions that need to be taken in improving the production of a product.

\section{Data Collection and Processing}

\section{Data Collection}

The data collected can be described as follows:

A. Primary data. Primary data is collected by direct observation or measurement, namely:

1. Open questionnaire data

2. Closed questionnaire data

3. Technical characteristics

4. Critical Part

5. Product Structure

B. Secondary data. Secondary data were obtained by interviewing the production department and company documentation data, including:

1. Production process sequence for Polycellonium packaging products.

2. Technical characteristics

3. Production data includes the production process.

The number of respondents in this closed questionnaire was 16 customers. Desires or expectations of customers identified for the attributes can be seen in the following Table 1:

\begin{tabular}{|c|c|}
\hline \multicolumn{2}{|c|}{ Table 1 Attributes of Polycellonium Packaging } \\
\hline No & Packaging Atributes \\
\hline 1. & Packaging dimansion \\
\hline 2. & Thickness of pakagung \\
\hline 3. & The packaging is not wringled \\
\hline 4. & Ink does not come off \\
\hline 5. & Packaging color \\
\hline 6. & Packaging text \\
\hline 7. & Packaging Design \\
\hline 8. & The packaging does not smell pungent \\
\hline 9. & Easy to cut packaging \\
\hline 10. & Packaging weight \\
\hline 11. & Packaging slippage \\
\hline 12. & No delamination \\
\hline 13 & Compliteness of analysis certificate \\
\hline 14. & Packaging packing \\
\hline
\end{tabular}

\section{Data Processing}

Validity and Reliability Test

Test the validity of using SPSS 16.0 software [8]. Variable is declared valid if the value of $r$ is calculated $\geq r$ table. In this case $r$ table if the significance level is $5 \%$ and the degree of freedom $\mathrm{db}=\mathrm{n}-2, \mathrm{n}$ is the number of questionnaires (16) then $\mathrm{db}=\mathrm{n}-2=16-2=14$, obtained $\mathrm{r}$ table $=0,532$.

After testing, in Corrected Item-Total Correlation it turns out that only 2 items have a value of $r<r$ table, that is, 14 items question Packaging Attributes have a value $r>r$ table, then all 14 Packaging Attributes are valid From the reliability test results obtained a Cronbach Alpha value of 0.924 . Then $0.924>0.60$ so that this questionnaire is reliable or reliable

\section{Building a House of Quality (HOQ) Matrix}

The steps that must be carried out in the process of forming the HOQ matrix are as follows :

1. Customers identification

2. Determine the Level of Interest Attributes

3. Develop a planning matrix

4. Establish Technical Requirements for Consumer Needs

5. Establishing Relationships Between Technical Requirements

6. Establish the Level of Relationship Between the Technical Characteristics of Products and Consumer Desires

7. Building the House of Quality (HOQ) Matrix

Based on the data obtained in the previous steps, the HoQ level 1 matrix is then made as shown in Figure 1 below 
Volume 8 Issue 8 August 2020

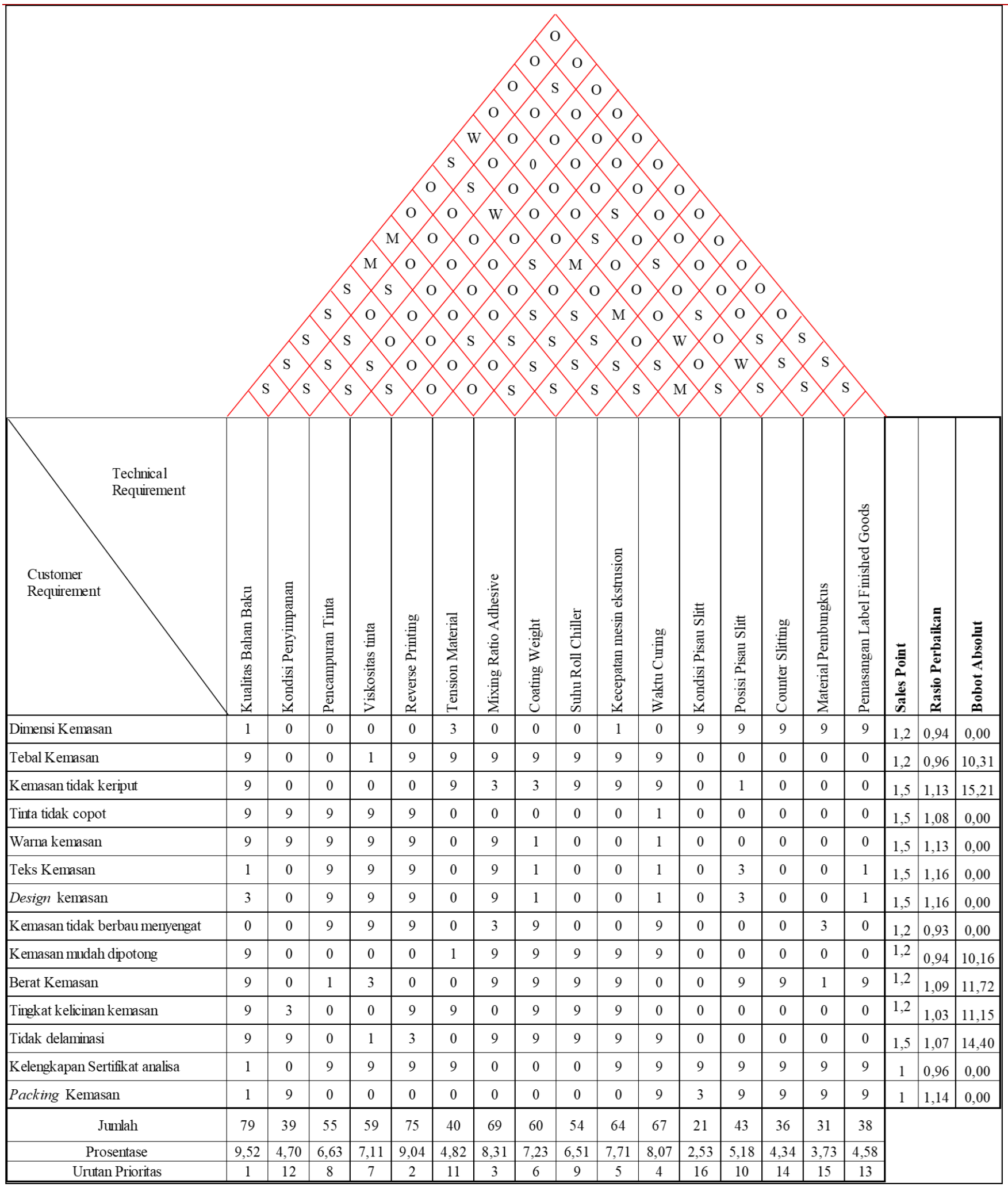

Figure 1. HOQ Matrix

\section{Establish Phase II Quality Function Deployment (QFD)}

The House of Quality technical matrix to process requirements is the second stage of the QFD stage. This matrix input is obtained from the previous matrix output, namely technical requirements (technical parameters) and the value of the Degrees of Interest which will be the normalization of weights. The stepd are following [9]

1. Weigth normalization

2. Requirement process 
iJournals: International Journal of Software \& Hardware Research in Engineering

ISSN-2347-9698

Volume 8 Issue 8 August 2020

3. Interaction of Technical Characteristics with Process Needs

4. Value of Technical Requirements with Process Requirements

5. Relationship Between Process Requirements

This House of Quality matrix explains what are the technical parameters and how to fulfill them. This matrix is made based on the merging of data processing from determining the normalization of weights to the interaction of process needs, but the results of this matrix cannot yet be determined in the company's operations.

Based on the data obtained in the previous steps, the HoQ level 2 matrix is then made as shown in Figure 2 below.

\begin{tabular}{|c|c|c|c|c|c|c|c|c|c|c|c|c|c|c|c|c|c|c|c|}
\hline Process Requirement & Bobot & 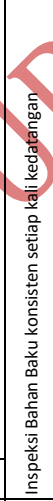 & 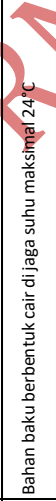 & 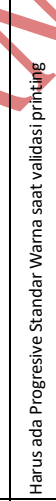 & 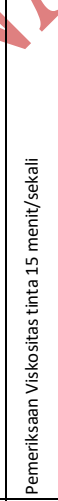 & 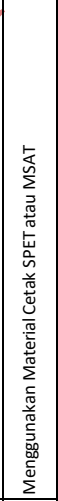 & 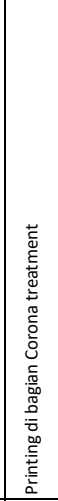 & 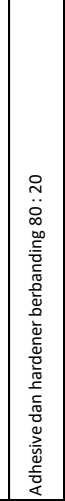 & 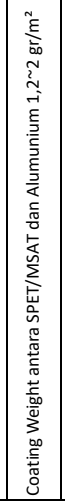 & 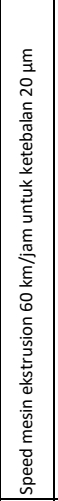 & 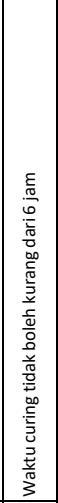 & 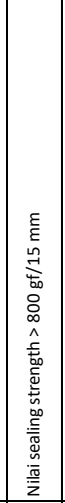 & 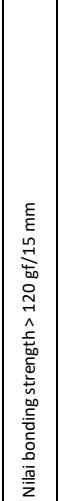 & 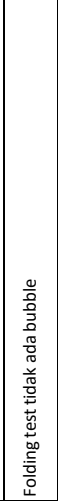 & 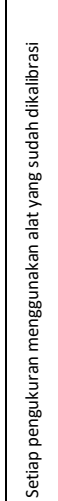 & 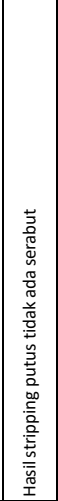 & 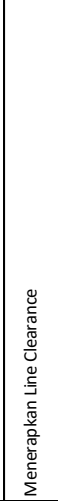 & 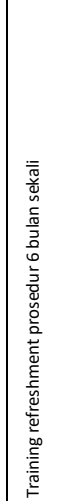 & 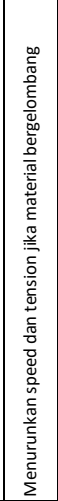 \\
\hline Inspeksi Bahan Baku sebelum digunakan produksi & 8,29 & 74,6 & 74,6 & 24,87 & 74,6 & 74,6 & 74,6 & & & & & & & & 74,6 & 74,6 & & 74,6 & \\
\hline Penyimpanan berdasarkan jenis material dan FIFO & 5,54 & 5,537 & 49,83 & 5,537 & 49,83 & & & 49,83 & & & 49,83 & & & & & & & & \\
\hline Menggunakan material yang Easy Tear & 3,04 & 27,39 & & & & 27,39 & 27,39 & & & & & & & & & 27,39 & & & \\
\hline Melakukan Validasi sebelum produksi printing & 5,51 & 49,57 & 49,57 & 49,57 & 49,57 & & 49,57 & & & & & & & & 49,57 & & 16,52 & 49,57 & \\
\hline Pengukuran Viskositas Tinta sebelum dan saat produksi berlangsung & 7,41 & 66,7 & 66,7 & 66,7 & 66,7 & & 7,412 & & & & & & & & 66,7 & & 22,23 & 66,7 & \\
\hline Penimbangan Coating Adhesive sebelum produksi & 8,35 & & & & & & & 75,18 & 75,18 & 25,06 & 75,18 & 75,18 & 75,18 & 75,18 & 75,18 & 75,18 & & 75,18 & \\
\hline Pengaturan Speed Mesin Ekstru sesuai thickness & 10,93 & & & & & 98,35 & & 98,35 & 98,35 & 98,35 & 98,35 & 98,35 & 98,35 & 98,35 & & 98,35 & & 98,35 & 98,35 \\
\hline Pengaturan Tension Material sesuai kondisi material & 8,61 & 25,82 & & & & 77,46 & & & 77,46 & 77,46 & & & & & & 77,46 & & 77,46 & 77,46 \\
\hline Inspeksi Jumbo Laminasi setelah curing (folding, sealing, bonding dan thickness) & 15,10 & 135,9 & & 135,9 & 135,9 & 135,9 & 135,9 & 135,9 & 135,9 & & 135,9 & 135,9 & 135,9 & 135,9 & 135,9 & 135,9 & & 135,9 & 135,9 \\
\hline Pengukuran Lebar hasil slitting & 3,88 & & & & & & & & & & & & & & 34,88 & & & 34,88 & 34,88 \\
\hline Pengukuran Diameter per Roll Finished Goods & 6,79 & 61,11 & & & & & & & 61,11 & 61,11 & & & & & 61,11 & & & 61,11 & \\
\hline Inspeksi Stripping Material hasil ekstrusion & 12,18 & 109,6 & & & & 109,6 & 109,6 & 109,6 & 109,6 & 109,6 & 109,6 & 109,6 & 109,6 & 109,6 & & 109,6 & & 109,6 & 109,6 \\
\hline Proses packing satu produk dalam satu waktu & 4,38 & & & & & 4,381 & & & & & & & & & & & 39,43 & 39,43 & \\
\hline \multicolumn{2}{|l|}{ Jumlah } & 556,2 & 240,7 & 282,5 & 376,6 & 527,7 & 404,5 & 468,9 & 557,6 & 371,6 & 468,9 & \begin{tabular}{|l|l|}
419 \\
\end{tabular} & \begin{tabular}{|l|l|}
419 \\
\end{tabular} & 419 & 497,9 & 598,5 & 78,19 & 822,8 & 456,2 \\
\hline \multirow{2}{*}{\multicolumn{2}{|c|}{\begin{tabular}{|c|} 
Prosentase \\
Urutan Prionitas
\end{tabular}}} & \begin{tabular}{|l}
6,983 \\
\end{tabular} & 3,022 & 3,547 & \begin{tabular}{|l}
4,727 \\
\end{tabular} & \begin{tabular}{|l|l|}
6,624 \\
\end{tabular} & 5,078 & \begin{tabular}{|l|}
5,886 \\
\end{tabular} & \begin{tabular}{|l|}
7,00 \\
\end{tabular} & 4,665 & 5,886 & 5,26 & \begin{tabular}{|l|}
5,26 \\
\end{tabular} & 5,26 & \begin{tabular}{|l}
, 251 \\
\end{tabular} & \begin{tabular}{|l}
7,513 \\
\end{tabular} & 0,982 & 10,33 & \begin{tabular}{|l|l|} 
\\
\end{tabular} \\
\hline & & 4 & 17 & 16 & 14 & 5 & 13 & 8 & 3 & 15 & 7 & 10 & 11 & 12 & 6 & 2 & 18 & 1 & 9 \\
\hline
\end{tabular}

Figure 2. HOQ level 2 matrix

\section{Establish Quality Function Deployment (QFD) Phase}

\section{III}

The House of Quality Matrix explains what the process requirements are and how to fulfill them. This matrix is made based on the merging of data processing from determining the normalization of weights to the interaction of quality procedures, the results of this matrix can already be determined in the company's operations. 
Volume 8 Issue 8 August 2020

This is because the output of this matrix is in the form of quality procedures which are a series of technical procedures in PT. XYZ in detail, measurable and concrete. The complete picture of this HOQ matrix is shown in Figure 3 below.

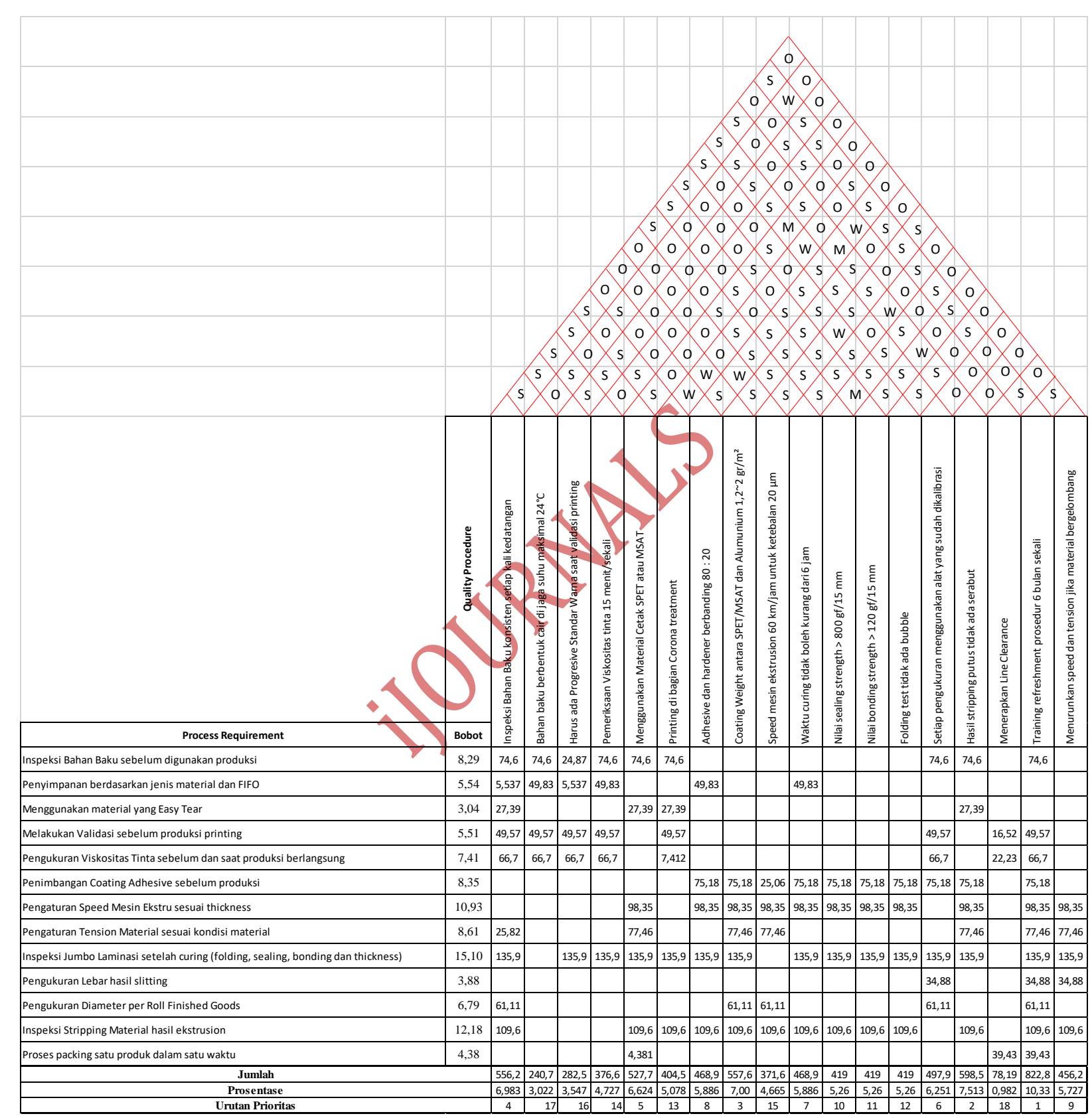

Figure 3. HOQ Matrix level 3

\section{Conclusion}

The conclusions that can be drawn from this study are:

1. House Of Quality Level 1. From the questionnaire distributed to 16 respondents obtained 14 items of Packaging Attributes as Customer Needs. To be able to meet the Customer Requirements, 16 Technical Requirements are determined. From the relationship between Customer Requirements and Technical Requirements we can focus on the 5 most important priority items namely Raw Material Quality, Reverse Printing, Mixing Adhesion Ratio, Curing Time, and Extrusion machine Speed. Therefore the main priorities above can be determined into Technical Requirements which are priorities to be developed first.

2. House Of Quality Level 2. Attributes of the Technical Requirements contested 16 are then announced into 13 Process Requirements. The need for this process is 
Volume 8 Issue 8 August 2020

determined by the research object company. From the relationship between Technical Requirements and Process Requirements, we can focus on the 5 most important priority items namely Jumbo Inspection of Laminates after curing (folding, sealing, bonding and thickness), Stripping Materials Inspection of extruded results, Extruding Machine Speed Adjustment according to thickness, setting Tension Material according to material conditions, and Weighing of the Coating Adhesive before production. Therefore the main priorities above can be determined into Process Requirements which are priorities to be developed beforehand.

3. House Of Quality Level 3. Process Requirements Attributes that won 13 are then announced into 18 Quality Procedures. Quality Procedure Attribute is determined by the company to respond to customer desires that have been formed in the Process Requirements attribute. From the relationship between the Process Requirements and the Quality Procedure, we can focus on the top 5 priority items, namely the 6month refresher training procedure, the results of stripping without fiber, the weight of the coating between the SPET / MSAT and the Aluminum $1.2 \sim 2$ $\mathrm{gr} / \mathrm{m}^{2}$, Inspection of Raw Materials every time you visit, and Using SPET or MSAT Printing Materials. Therefore the main priorities above can be determined as a Quality Procedure which is a priority to be developed first.

4. Development for packaging as follows:

a. The printing process uses SPET or MSAT material using the Reverse Printing system, which is the print or ink position in the PE sandwich section. Printed with a machine with Rotogravure system. So that the prints can last a long time and the packaging does not cause a pungent odor. SPET and MSAT materials are also easier to cut.

b. For thick PE sandwich used is $20 \mu \mathrm{m}$. With this thickness the bonding value between SPET / MSAT with PE and PE with ALU is quite high at $\geq 120 \mathrm{gf} /$ $15 \mathrm{~mm}$. The packaging is still easy to cut and the results are not stringy stripping.

c. The ALU used is $12 \mu \mathrm{m}$ in thickness and $15 \mu \mathrm{m}$ in thickness. With the thickness of the ALU the barrier to protecting drugs is good enough, one of them is protection from water vapor and influences the drug expiration period. If the ALU used is too thin it will affect the results of packaging that is easily wrinkled during the production process.

d. The sealing part of the packaging used is PE or EAA material with a thickness of $35 \mu \mathrm{m}$. With this thickness, it shows a good Sealing Strength value yaitu $700 \mathrm{gf} / 15 \mathrm{~mm}$. This can prevent material leakage.

\section{ACKNOWLEDGMENTS}

The authors give special appreciation to Universitas Mercu Buana Jakarta and Sekolah Tinggi Teknologi Bekasi for research funding.

\section{REFERENCES}

[1] P. Kotler and G. Amstrong, Prinsip-Prinsip Pemasaran. Jakarta: Erlangga, 2012.

[2] W. imam djati, Perancangan dan Pengembangan Produk. Yogyakarta: UII Press, 2003.

[3] Z. Baran and S. M. Yıldız, "Quality Function Deployment and Application on a Fast Food Restaurant," Int. J. Bus. Soc. Sci., vol. 6, no. 9, pp. 122-131, 2015.

[4] A. Maisyaroh and T. Husein, "Perbaikan Kualitas Anti Nyamuk Aerosol Produksi PT.XYZ dengan Menggunakan Metode Quality Function Deployment (QFD)," SINERGI, 2015, doi: 10.22441/sinergi.2015.2.003.

[5] D. J. I. K. M. D. Perindustrian, Kemasan Flexible. Departemen Perindustrian, 2007.

[6] H. Purba, Humiras, M. Syamsul Maarif, I. Yuliasih, and A. Hermawan, "Product development of chocolate with quality function deployment approach: A case study in SMEs chocolate industry in Indonesia," 2018, doi: 10.1088/1755-1315/209/1/012011.

[7] K. T. Ulrich and S. D. Eppinger, Product Design and Development: Fifth Edition. 2012.

[8] S. Ariyanti, C. Soekardi, R. T. Suhada, and W. Y. Pratama, "Rancang bangun mesin penyangrai kacang tanah pada Industri Mochi di Sukabumi," J. Energi dan Manufaktur Vol, vol. 10, no. 2, pp. 53-59, 2017.

[9] P. Yuliarty and H. Ardiwijayanta, "The design of front and back grille of KAD-927 B fan with Nigel Cross Approach at PT. X (A Manufacturer of Household Appliances)," in IOP Conference Series: Materials Science and Engineering, 2018, vol. 453, no. 1, doi: 10.1088/1757899X/453/1/012035. 